\title{
PERLINDUNGAN HUKUM TERHADAP TKI YANG BEKERJA DI LUAR NEGERI (KAJIAN YURIDIS TERHADAP SINKRONISASI PERATURAN PERUNDANG-UNDANGAN PENEMPATAN DAN PERLINDUNGAN TKI)
}

\author{
Lalu Husni ${ }^{1}$
}

\begin{abstract}
Act Number 39 Year 2004 on Placement and Legal Protection of Indonesian Worker Employed Abroad is not synchronized both vertically and horizontally yet. It is, vertically, not reflect the Article 28D (2) jo Article 281 (4) of the 1945 Constitution. Besides that, is not synchronic with the Act Number 39 Year 2004 particularly in controlling the protection of TKIs. Article 92 (1) Act Number 39 Year 2004 authorize the control of placement of TKIs to the institution that responsible for the employment at the Government, Province Government, and Kabupaten/City Government. The same authority is given to BNP2TKI by Perpres No. 81 Year 2006 (Article 14 (2)). As a consequence, the competing and inconsistent in controlling the TKIs protection take place. Likewise the competing and inconsistent between the Decision of the Ministry of Man Power and Transmigration Number 22/MEN/XXI/2008. Horizontally, no synchronization between Act Number 39 Year 2004 and Act Number 39 Year 1999 on Human Rights especially related to the elaboration of the concept of work as a part of human rights and state responsibility in protection, fulfilling and enforcing it. The same is happened in the Act Number 32 Year 2004 on Local Government related to the authority in protecting TKIs between the Government and Local Government.
\end{abstract}

Kata kunci: sinkronisasi, perlindungan hukum, TKI

1 Penulis adalah Dosen Fakultas Hukum Universitas Mataram NTB. Alamat korespondensi: husnimuslim@yahoo.co.id. 


\section{Pendahuluan}

Salah satu persoalan pelik yang dihadapi oleh bangsa Indonesia di bidang ketenagakerjaan adalah tingginya jumlah pengangguran. Pengangguran terjadi akibat pertumbuhan angkatan kerja yang tidak diimbangi dengan kemampuan menyediakan lapangan pekerjaan. Berdasarkan hasil survei Badan Pusat Statistik (BPS) pada bulan Pebruari 2007 terdapat 10,55 juta orang penganggur terbuka (open unemployment) akibatnya tidak memiliki sumber penghasilan sama sekali. Jumlah ini menurut Hayati akan terus meningkat sesuai dengan asumsi Bappenas bahwa (1) setiap tahun sedikitnya terdapat 2,5 juta orang angkatan kerja baru, (2) apabila pertumbuhan ekonomi mencapai 5,5\% setahun, maka lapangan pekerjaan baru yang tersedia mencapai 1,5 juta. Dengan demikian, setiap tahun masih akan ada 1 juta orang penganggur baru. ${ }^{2}$

Berbagai upaya telah dilakukan oleh pemerintah untuk mengurangi jumlah angka pengangguran, salah satunya adalah dengan mengisi kesempatan kerja di luar negeri. Kebijakan penempatan tenaga kerja ke luar negeri bagi Indonesia sampai dengan saat ini masih dipandang relevan, mengingat bangsa Indonesia masih menghadapi banyak permasalahan ketenagakerjaan seperti jumlah angkatan kerja yang masih tinggi, angka pengangguran yang semakin meningkat, rendahnya kualitas tenaga kerja, serta tingkat upah yang masih rendah jika dibandingkan dengan negara lain di kawasan Asia Tenggara. Dengan kondisi ini, maka adanya kesempatan kerja di luar negeri sangat mendapatkan respon dari masyarakat terutama karena upah/gaji yang ditawarkan cukup tinggi serta motivasi untuk ingin memperbaiki/merubah nasib ke arah yang lebih baik.

Indonesia merupakan negara pengirim (sending country) buruh migran terbesar kedua di Asia Tenggara setelah Philipina. ${ }^{3}$ Menurut catatan Departemen Tenaga Kerja dan Transmigrasi (selanjutnya disingkat Depnakertrans), sampai dengan bulan Juni 2006 jumlah buruh migran Indonesia mencapai 4.488 .741 orang. Sebagian besar buruh migran ini berasal dari daerah pedesaan. Secara makro, seperti yang tercatat pada Depnakertrans, uang yang dikirim (remittance) oleh buruh migran Indonesia pada tahun 2006 berjumlah US\$ 6,5 milyar atau sekitar Rp. 58 triliyun. Jumlah Tenaga Kerja Indonesia (selanjutnya disingkat TKI) yang bekerja di

${ }^{2}$ Hidayati, "Menghitung Angka Pengangguran dan Harapan yang Raib", Kompas, Tanggal, 12 Pebruari, 2005, Jakarta, hal. 27.

${ }^{3}$ Tita Naovalita dkk, "Perlindungan Sosial Buruh Migran Perempuan", Proseding Seminar, The World Bank bekerjasama dengan Kementerian Kesejahteraan Rakyat RI, Jakarta, 2-3 Mei 2006, hal 64. 
luar negeri terus mengalami peningkatan, sampai akhir tahun 2008 jumlah TKI yang bekerja di luar negeri meningkat menjadi enam juta orang dengan remittance mencapai $\mathrm{Rp} .130$ triliun. $^{4}$

Meskipun banyak mendatangkan devisa bagi negara dan daerah serta turut serta memecahkan persoalan ketenagakerjaan di dalam negeri, perlindungan yang diperoleh para buruh migran masih sangat terbatas ${ }^{5}$. Kondisi ini terbukti dari banyaknya kasus pelanggaran hak buruh migran yang terjadi setiap tahunnya baik pada tahap pra penempatan, pada saat penempatan, maupun setelah penempatan (post placement). Mekanisme penyelesaian atas berbagai kasus yang dihadapi buruh migranpun belum optimal sebagaimana yang diharapkan. Hal ini tidak sebanding dengan sumbangan yang mereka berikan, baik di tingkat lokal maupun nasional.

Untuk melindungi TKI yang bekerja di luar negeri (work in overseas), pemerintah pada tanggal 18 Oktober 2004 menetapkan Undang-undang Nomor 39 Tahun 2004 tentang Penempatan dan Perlindungan TKI di Luar Negeri (LNRI Tahun 2004 Nomor 133, TLNRI Nomor 4445). Dalam Undang-undang Nomor 39 Tahun 2004 tentang Penempatan dan Perlindungan TKI terdapat norma samar atau kabur (vage normen), misalnya dalam Pasal 95 yang mengatur mengenai fungsi dan tugas Badan Nasional Penempatan dan Perlindungan TKI (BNP2TKI).

Adanya norma kabur yang berkenaan dengan tugas BNP2TKI sebagai pelaksana kebijakan (policy implementation) yang berarti melaksanakan semua kebijakan yang dikeluarkan oleh Menteri Tenaga Kerja dan Transmigrasi (selanjutnya disingkat Menakertrans) sebagai regulator dan tugas melakukan penempatan antara pemerintah dengan pemerintah negara pengguna TKI atau pengguna berbadan hukum di negara tujuan penempatan, serta memberikan pelayanan, mengkoordinasikan, dan melakukan pengawasan mengenai dokumen, pembekalan akhir pemberangkatan (PAP), penyelesaian masalah, pemberangkatan sampai pemulangan TKI, peningkatan kualitas calon TKI dan kesejahteraannya telah menimbulkan konflik kewenangan antara Menakertrans dengan Kepala BNP2TKI.

Untuk melaksanakan lebih lanjut Undang-undang Nomor 39 Tahun 2004, pemerintah telah mengeluarkan berbagai peraturan pelaksanaan, antara lain Peraturan Presiden RI Nomor 81 Tahun 2006 tentang BNP2TKI, Pemenakertrans RI Nomor 18 Tahun 2007 tentang Pelaksanaan Penempatan dan Perlindungan TKI di Luar Negeri jo. Permenakertrans RI Nomor 22

${ }^{4}$ Devisa TKI Tembus Rp. 130 Triliun, Jawa Pos, 16 Desember 2008, hal. 7,

${ }^{5}$ Tita Naovalita dkk, Loc. Cit. 
Tahun 2008, Permenakertrans No. 20 Tahun 2007 tentang Asuransi Tenaga Kerja Indonesia dan peraturan pelaksanaan lainnya.

Selain itu, Undang-undang Nomor 39 Tahun 2004 tentang Penempatan dan Perlindungan TKI di Luar Negeri juga berkaitan dengan beberapa undang-undang yang sederajat, misalnya Undang-undang Nomor 39 Tahun 1999 tentang HAM. Kaitannya dengan Undang-undang HAM sebagaimana disebutkan dalam konsideran menimbangnya bahwa bekerja merupakan bagian dari HAM. Demikian juga dengan Undang-undang Nomor 32 Tahun 2004 tentang Pemerintahan Daerah khususnya yang berkenaan dengan kewenangan Pemerintah Daerah dalam bidang penempatan dan perlindungan TKI.

Peraturan pelaksanaan sebuah undang-undang harus sinkron dengan peraturan diatasnya (vertikal), demikian juga dengan peraturan perundanganundangan lain yang sederajat (horizontal) sehingga dapat memperkuat keberlakuannya (its validity) secara yuridis. Demikian halnya dengan Undang-undang Nomor 39 Tahun 2004 tentang Penempatan dan Perlindungan TKI di Luar Negeri. Karena itu perlu dikaji sinkronisasinya dalam kaitannya dengan belum terlindunginya TKI secara layak.

\section{Sinkronisasi Vertikal}

Sinkronisasi berasal dari kata dasar sinkron yang berarti sejalan, sesuai, selaras. ${ }^{6}$ Dalam bahasa Inggris dikenal dengan istilah synchronize yang berarti mengoperasikan, menggerakkan, menggeser dsb. Pada waktu, dengan kecepatan yang sama dsb (to operate, move, turn, etc. at the same time, speed, etc). ${ }^{7}$ Jadi sinkronisasi yang dimaksudkan adalah kesesuaian atau keselarasan antara peraturan perundangan yang satu dengan lainnya dalam derajat yang berbeda atau secara vertikal.

Dalam kata bahasa Indonesia istilah yang hampir sama maknanya dengan sinkron adalah harmoni yang dapat berarti keselarasan, kecocokan, keserasian. $^{8}$ Namun demikian makna harmonisasi hukum lebih luas dari sinkronisasi. Sinkronisasi merupakan bagian dari kajian harmonisasi, namun

6 "Kamus Besar Bahasa Indonesia", (Departeman Pendidikan dan Kebudayaan, Balai Pustaka, Jakarta, 1997), hal. 946. hal. 1211.

${ }^{7}$ AS Homby, "Oxford Advanced Leaner's Dictionary", (Oxford University, 1995),

${ }^{8}$ M. Dahlan Al Barry, dalam Kusnu Goesniadhie S, "Harmonisasi Hukum dalam Perspektif Perundang-undangan”, (JP Books, Surabaya, 2006), hal. 23. 
sinkronisasi tidak dapat diaplikasikan dalam kajian norma dan sistem hukum global atau transnasional. ${ }^{9}$ Sinkronisasi peraturan perundang-undangan secara vertikal yang dikaji apakah suatu peraturan perundang-undangan yang berlaku bagi suatu bidang kehidupan tertentu tidak saling bertentangan, apabila dilihat dari sudut hirarki perundang-undangan tersebut. ${ }^{10}$ Menurut Arief Sidharta inkonsistensi peraturan perundang-undangan secara vertikal dari segi format peraturan yakni peraturan yang lebih rendah bertentangan dengan peraturan yang lebih tinggi. ${ }^{11}$ Dengan demikian kajian sinkronisasi vertikal dalam tulisan ini adalah peraturan perundangan-undangan di bidang penempatan dan perlindungan TKI di luar negeri sesuai dengan teori hierarki atau jenjang norma hukum (Stufenbautheorie) dari Hans Kelsen bahwa norma hukum itu berjenjang dan berlapis-lapis dalam suatu tata susunan norma. Norma yang lebih rendah bersumber dan berdasar pada norma yang lebih tinggi, demikian seterusnya sampai pada norma yang tidak dapat ditelusuri lebih lanjut dan bersifat hipotetis dan fiktif yakni norma dasar (grundnorm). Penjabaran teori ini dalam tata hukum Indonesia sebagaimana tertuang dalam Pasal 7 ayat (1) Undang-undang Nomor 10 Tahun 2004 tentang Pembentukan Peraturan Perundang-undangan sebagai berikut:

1. Undang-Undang Dasar Negara Republik Indinesia Tahun 1945;

2. Undang-undang/Peraturan Pemerintah Pengganti Undang-undang;

3. Peraturan Pemerintah;

4. Peraturan Presiden;

5. Peraturan Daerah.

Dalam pembukaan UUD 1945 terdapat empat pokok pikiran yang tidak lain adalah Pancasila. Pancasila selain sebagai cita hukum (rechtsidee) juga sebagai Norma Fundamental Negara (Staatsfundamentalnorm), yakni merupakan norma dasar atau norma tertinggi bagi berlakunya semua norma hukum. Dalam kedudukan ini Pancasila disebut juga sebagai sumber dari segala sumber hukum, artinya semua produk hukum yang berlaku di Indonesia harus berdasar dan bersumber dari Pancasila. Sedangkan UUD

${ }^{9}$ Kusnu Goesniadhie S, Ibid, hal. 24.

${ }^{10}$ Soerjono Soekanto dan Sri Mamudji, "Penelitian Hukum Normatif Suatu Tinjauan Ringkas", (Rajawali Pers, Jakarta, 1985), hal. 19.

${ }^{11}$ Arif Sidharta dalam Gatot Dwi Hendro, Kerangka Hukum Pengelolaan Ekosistem Terumbu Karang untuk Mendukung Pemanfaatan Berkelanjutan Keanekaragaman Hayati Lautan, Disertasi, Program Pascasarjana Universitas Airlangga, Surabaya, 2007, hal. 289. 
1945 merupakan hukum dasar tertulis tertinggi yang merupakan sumber hukum bagi peraturan perundang-undangan di bawahnya.

Sesuai dengan ketentuan dalam Pasal II Aturan Peralihan UUD 1945 yang menyebutkan bahwa "segala badan negara dan peraturan yang ada masih langsung berlaku, selama belum diadakan yang baru menurut UndangUndang Dasar ini", maka aturan yang ada yang berkaitan dengan pengerahan orang Indonesia yang bekerja ke luar negeri yakni "Ordonansi tentang Pengerahan Orang Indonesia untuk Melakukan Pekerjaan di Luar Negeri atau Werving van Indoneiers voor het verrichten van arbeid buiten Indonesia (Staatsblad Tahun 1887 Nomor 8) masih berlaku.

Setelah bangsa Indonesia merdeka, pengerahan tenaga kerja Indonesia khususnya ke luar negeri dimulai tahun 1970 yang diatur melalui Permenaker Nomor 4 Tahun 1970 tentang Pengerahan Tenaga Kerja jo. Permenaker Nomor 1 Tahun 1983 tentang Perusahaan Pengerahan Tenaga Kerja Indonesia ke Luar Negeri dan selanjutnya beberapa kali disempurnakan dengan Permenaker Nomor 05 Tahun 1988 jo. Permenaker Nomor 01 Tahun 1991 tentang Antar Kerja Antar Negara (AKAN) jo. Permenaker Nomor 02/MEN/1994 tentang Penempatan Tenaga Kerja di Dalam dan di Luar Negeri jo. Kepmenaker Nomor 204/MEN/1999 tentang Penempatan Tenaga Kerja Indonesia ke Luar Negeri jo. Kepmenaker Nomor 104 Tahun 2000 tentang Penempatan Tenaga Kerja Indonesia ke Luar Negeri jo. Kepmenaker Nomor 104 A Tahun 2000 tentang Penempatan Tenaga Kerja Indonesia ke Luar Negeri.

Gerakan reformasi yang berhasil menumbangkan pemerintahan orde baru telah membangkitkan semangat untuk melakukan koreksi/perbaikan terhadap kekurangan pemerintahan masa lalu termasuk di bidang hukum yang masih banyak menggunakan produk hukum peninggalan kolonial dan atau produk hukum nasional yang dipandang sudah tidak sesuai dengan perkembangan dan kebutuhan hukum masyarakat. Oleh karena itu, pada tanggal 25 Maret 2003 pemerintah menetapkan Undang-undang Nomor 13 Tahun 2003 tentang Ketenagakerjaan (Lembaran Negara RI Tahun 2003 Nomor 39, Tambahan Lembaran Negara RI Nomor 4279). Undang-undang ini mencabut enam ordonansi peninggalan Belanda yang masih berlaku, salah satunya adalah Ordonansi tentang Pengerahan Orang Indonesia untuk Melakukan Pekerjaan di Luar Negeri atau Werving van Indoneiers voor het verrichten van arbeid buiten Indonesia (Staatsblad Tahun 1887 Nomor 8). Dalam Undang-undang ini disebutkan bahwa ketentuan mengenai penempatan tenaga kerja di luar negeri diatur dengan undang-undang (Pasal 34). Untuk melaksanakan amanat Pasal 34 Undang-undang ini, maka pada tanggal 18 Oktober 2004 pemerintah menetapkan Undang-undang Nomor 39 Tahun 2004 tentang Penempatan dan Perlindungan TKI di Luar Negeri 
(Lembaran Negara RI Tahun 2004 Nomor 133, Tambahan Lembaran Negara RI Nomor 4445).

Pada bagian konsideran menimbang Undang-undang Nomor 39 Tahun 2004 huruf a, d menyebutkan bahwa bekerja merupakan HAM yang wajib dijunjung tinggi, dihormati, dan dijamin penegakannya. Negara wajib menjamin dan melindungi hak asasi warga negaranya yang bekerja baik di dalam maupun di luar negeri berdasarkan prinsip persamaan hak, demokrasi, keadilan sosial, kesetaraan dan keadilan gender, anti diskriminasi, dan anti perdagangan manusia.

Berdasarkan pertimbangan pada bagian konsideran tersebut, jelaslah bahwa norma dasar yang terkandung dalam Undang-Undang Dasar Negara RI Tahun 1945 telah dijadikan sumber inspirasi dalam pembentukan Undang-undang Nomor 39 Tahun 2004 tentang Penempatan dan Perlindungan TKI di Luar Negeri, khususnya pengakuan bekerja sebagai bagian dari HAM (Pasal 28D ayat 2), kewajiban negara untuk menjamin dan melindungi hak asasi warga negaranya yang bekerja baik di dalam maupun di luar negeri (Pasal 28I ayat 4), dan kebijakan penempatan tenaga kerja ke luar negeri merupakan suatu upaya dari pemerintah untuk memenuhi kewajiban konstitusioanalnya menyediakan lapangan pekerjaan dan penghasilan yang layak bagi kemanusiaan (Pasal 27 ayat 2 UUD 1945).

Persoalan selanjutnya adalah belum dijabarkannya norma dasar yang terdapat dalam UUD Negara RI Tahun 1945 ke dalam pasal-pasal Undangundang Nomor 39 Tahun 2004 tentang Penempatan dan Perlindungan TKI di Luar Negeri. Undang-undang ini lebih bernuansa penempatan dari pada perlindungan. Dari 109 pasal yang diatur, hanya 8 (delapan) pasal yang mengatur mengenai perlindungan itupun perlindungan pada saat penempatan saja. Sedangkan perlindungan pra penempatan dan purna penempatan tidak diatur secara tegas. Padahal dalam 7 huruf e menyebutkan bahwa kewajiban pemerintah untuk memberikan perlindungan kepada TKI selama masa sebelum pemberangkatan, masa penempatan, dan purna penempatan.

Selain mengkaji insinkronosasi Undang-undang Nomor 39 Tahun 2004 tentang Penempatan dan Perlindungan TKI di Luar Negeri dengan UUD Negara Republik Indonesia Tahun 1945 sebagai hukum dasar tertulis tertinggi di Indonesia, juga akan dikaji ketidaksinkronan antara peraturan pelaksanaannya dengan undang-undang tersebut. Peraturan pelaksanan dimaksud adalah Peraturan Presiden RI Nomor 81 Tahun 2006 tentang Badan Nasional Penempatan dan Perlindungan Tenaga Kerja Indonesia. Peraturan Presiden ini dibentuk sebagai pelaksanaan amanat Pasal 97 Undang-undang Nomor 39 Tahun 2004 yang menyebutkan bahwa ketentuan mengenai pembentukan, fungsi, tugas, struktur organisasi, dan tata kerja 
Badan Nasional Penempatan dan Perlindungan TKI diatur dengan Peraturan Presiden.

Dalam Pasal 2 Perpres Nomor 81 Tahun 2006 menyebutkan BNP2TKI beranggotakan wakil-wakil instansi pemerintah terkait mempunyai fungsi pelaksanaan kebijakan di bidang penempatan dan perlindungan TKI di luar negeri secara terkoordinasi dan terintegrasi. Dalam melaksanakan fungsi sebagaimana dimaksud dalam Pasal 2 b, menyebutkan BNP2TKI menyelenggarakan tugas "memberikan pelayanan, mengkoordinasikan, dan melakukan pengawasan mengenai: (1) dokumen; (2) pembekalan akhir pemberangkatan (PAP); (3) penyelesaian masalah; (4) sumber-sumber pembiayaan; (5) pemberangkatan sampai pemulangan; (6) peningkatan kualitas calon Tenaga Kerja Indonesia; (7) informasi; (8). kualitas pelaksana penempatan TKI; dan (9) peningkatan kesejahteraan TKI dan keluarganya.

Berdasarkan uraian tugas (job discription) di atas, jelaslah bahwa BNP2TKI selain memberikan pelayanan, mengkoordinasikan, juga melakukan pengawasan terhadap pelaksanaan penempatan dan perlindungan TKI mulai dari pengurusan dokumen pemberangkatan, penempatan, sampai pemulangan. Ketentuan dalam Pasal 2 Perpres Nomor 81 Tahun 2006 ini tidak sinkron dengan ketentuan dalam Pasal 92 Undang-undang Nomor 39 Tahun 2004 yang menyebutkan bahwa pengawasan terhadap penyelenggaraan penempatan dan perlindungan TKI di luar negeri dilaksanakan oleh instansi yang bertanggung jawab di bidang ketenagakerjaan pada pemerintah, pemerintah propinsi, pemerintah kabupaten/kota. Menurut hemat penulis tugas pengawasan sebaiknya dilakukan sesuai dengan ketentuan Pasal 92 Undang-undang Nomor 39 Tahun 2004 yakni dilakukan oleh instansi yang bertanggungjawab di bidang ketenagakerjaan pada pemerintah, pemerintah propinsi, pemerintah kabupaten/kota karena pada lembaga pemerintah ini telah tersedia lembaga/institusi pengawas ketenagakerjaan yang memang dibentuk untuk melaksanakan tugas tersebut. Selain itu BNP2TKI mempunai fungsi sebagai pelaksana kebijakan penempatan dan perlindungan TKI, sehingga kurang tepat badan pelaksana sekaligus mengawasi pelaksanaan tugasnya sendiri.

Mengenai pengawasan ini, Undang-undang Nomor 13 Tahun 2003 tentang Ketenagakerjaan Pasal 176 menyebutkan bahwa "pengawasan ketenagakerjaan dilakukan oleh pegawai pengawas ketenagakerjaan yang mempunyai kompetensi dan independen guna menjamin pelaksanaan peraturan perundang-undangan ketenagakerjaan". Dalam Pasal 178 ayat (1) disebutkan bahwa."pengawasan ketenagakerjaan dilaksanakan oleh unit kerja tersendiri pada instansi yang lingkup tugas dan tanggungjawabnya di bidang ketenagakerjaan pada pemerintah pusat, pemerintah provinsi, dan pemerintah kabupaten/kota". 
Undang-undang Nomor 3 Tahun 1951 tentang Pernyataan Berlakunya Undang-undang Nomor 23 Tahun 1948 tentang Pengawasan Perburuhan mengatur mengenai wewenang pengawas perburuhan yaitu (1) mengawasi berlakunya peraturan perundang-undangan perburuhan pada khususnya, (2) mengumpulkan bahan-bahan keterangan tentang soal-soal hubungan kerja dan keadaan perburuhan dalam arti yang seluas-luasnya guna membuat Undang-undang dan peraturan perburuhan lainnya, (3) menjalankan pekerjaan lain yang diserahkan sesuai dengan peraturan perundangundangan.

Berdasarkan landasan normatif di atas, jelaslah bahwa pengawasan perburuhan/ketenagakerjaan yang dilakukan oleh pegawai pengawas dimaksudkan sebagai upaya preventif untuk menghindari terjadinya penyimpangan terhadap pelaksanaan peraturan perundang-undangan di bidang ketenagakerjaan yang seringkali dilakukan oleh pihak pengusaha terhadap buruh/pekerja. P. Nicolai berpendapat "het toezich dat bestuursorganen kunnen uitoefenen op de naleving van de bij of krachtens de wet gestelde voorschriften en van de bij besluit individueel opgeledge verplichtingen (organ pemerintahan dapat melaksanakan ketaatan pada atau berdasarkan undang-undang yang ditetapkan secara tertulis dan pengawasan terhadap keputusan yang meletakkan kewajiban kepada individu). ${ }^{12}$ Selain itu menurut Ten Berge pengawasan merupakan salah satu instrumen penegakan hukum administrasi negara. Pelaksanaannya dilakukan dengan cara penyuluhan, pemantauan dan sejenisnya. ${ }^{13}$

Dalam Pasal 23 ayat (1) Perpres Nomor 81 Tahun 2006 menyebutkan bahwa untuk kelancaran pelaksanaan pelayanan penempatan Tenaga Kerja Indonesia, dibentuk BP3TKI di Ibukota Propinsi dan/atau tempat pemberangkatan TKI yang dianggap perlu. BP3TKI mempunyai tugas memberikan kemudahan pelayanan pemerosesan seluruh dokumen penempatan, perlindungan dan penyelesaian masalah Tenaga Kerja Indonesia secara terkoordinasi dan terintegrasi di wilayah kerja masing-masing BP3TKI (Pasal 24 ayat 1). Namun dalam Pasal 42 Permenakertrans Nomor 18 Tahun 2007 tentang Pelaksanaan Penempatan dan Perlindungan Tenaga Kerja di Luar Negeri sebagai peraturan pelaksanaan Undang-undang Nomor 39 Tahun 2004 menetapkan bahwa BP3TKI, pemerintah propinsi, pemerintah kabupaten/kota dengan instansi pemerintah lainnya terkait

12 P. Nicolai, dalam Ridwan HR, "Hukum Administrasi Negara", (Jakarta: RajaGrafindo Persada, 2007), hal. 311.

${ }^{13}$ Ten Berge dalam Philipus M. Hadjon, Penegakan Hukum Administrasi dalam Pengelolaan Lingkungan Hidup, Makalah Lokakarya Penegakan Hukum Lingkungan, Unair, Surabaya, 1996, hal. 6. 
melakukan koordinasi dalam memberikan pelayanan penempatan dan perlindungan TKI sesuai tugas masing-masing. Tugas yang diemban oleh BP3TKI berdasarkan kedua peraturan di atas tidak sinkron, berdasarkan Pasal 24 ayat (1) Perpres Nomor 81 Tahun 2006 memberikan kemudahan pelayanan pemerosesan seluruh dokumen penempatan, perlindungan, sedangkan berdasarkan Pasal 42 Permenakertrans Nomor 18 Tahun 2007 melakukan koordinasi dalam memberikan pelayanan penempatan dan perlindungan TKI. Ketidak sinkronan/antinomi norma ini secara vertikal akan berdampak terhadap validitas norma itu sendiri dan pada akhirnya berpengaruh terhadap efektivitasnya, seperti dikemukakan Antony Allot " Valid norm a norm which is formally correct, having been made in due form. A valid norm which secures a high degree of compliance: i.e. one which is actually complied with. ${ }^{14}$ Validitas norma hukum diperoleh karena pembentukannya didasarkan pada norma yang lebih tinggi yakni kesesuaian norma hukum dengan peraturan perundang-undangan di atasnya.

Sejalan dengan ditetapkannya Peraturan Pemerintah Nomor 38 Tahun 2007 tentang Pembagian Urusan Pemerintahan Antara Pemerintah, Pemerintahan Daerah Provinsi dan Pemerintahan Daerah Kabupaten/Kota, maka Permenakertans Nomor 18 Tahun 2007 diganti dengan Permenakertrans Nomor 22 Tahun 2008 untuk disesuaian dengan semangat pelaksanaan otonomi daerah yang diatur dalam Peraturan Pemerintah tersebut.

Selain untuk disesuaikan dengan semangat otonomi daerah, dikeluarkannya Permenakertrans Nomor 22 Tahun 2008 menggantikan Permenakertrans Nomor 18 Tahun 2007 sebagaimana disebutkan dalam Pasal 2 dimaksudkan untuk mengatur penempatan dan perlindungan TKI di luar negeri yang dilaksanakan oleh PPTKIS. Hal ini didasarkan atas ketentuan Pasal 95 ayat 2 Undang-undang Nomor 39 Tahun 2004 jo. Pasal 3 ayat (1) huruf a Peraturan Pemerintah Nomor 81 Tahun 2006 yang menyebutkan bahwa tugas BNP2TKI adalah "melakukan penempatan atas dasar perjanjian secara tertulis antara pemerintah dengan pemerintah negara pengguna TKI atau pengguna berbadan hukum di negara tujuan penempatan sebagaimana dimaksud dalam Pasal 11 ayat (1)". Dalam Pasal 11 ayat (2) menyebutkan mengenai tata cara pelaksanaan penempatan TKI oleh pemerintah diatur lebih lanjut dengan Peraturan Pemerintah.

Berdasarkan pasal di atas, jelaslah bahwa BNP2TKI bertugas melakukan penempatan TKI antar pemerintah dengan pemerintah negara pengguna TKI atau pengguna berbadan hukum. Kata "atau" berarti alternatif kalau sudah dengan pemerintah negara pengguna berarti tidak dengan

${ }^{14}$ Antony Allot, "The Limits of Law", (London: Butterworths, 1980), hal. 30. 
pengguna berbadan hukum milik pemerintah maupun swasta dan/atau perorangan. Selama ini yang ditangani oleh BNP2TKI adalah penempatan TKI antara pemerintah dengan pemerintah negara pengguna (Governement to Governement atau $G$ to $G$ ). Berarti penempatan TKI untuk kepentingan badan hukum dan/atau perorangan di luar negeri menjadi kewenangan PPTKIS. Berdasarkan argumen ini dikeluarkannya Kepmekaertrans No. 22 Tahun 2008 yakni untuk mengatur penempatan dan perlindungan TKI di luar negeri yang dilaksanakan oleh PPTKIS dapat dibenarkan secara hukum. Sementara Peraturan Pemerintah untuk mengatur penempatan TKI yang dilakukan oleh pemerintah sampai dengan saat ini belum dikeluarkan.

Kewenangan lain dari BNP2TKI sesuai dengan ketentuan Pasal 25 ayat (2) b Undang-undang Nomor 39 Tahun 2004 jo. Pasal 3 ayat (1) huruf b Peraturan Pemerintah Nomor 81 Tahun 2006 adalah memberikan pelayanan, mengkoordinasikan, dan melakukan pengawasan mengenai dokumen, PAP, penyelesaian masalah, sumber-sumber pembiayaan, pemberangkatan sampai pemulangan, peningkatan kualitas calon TKI, informasi, kualitas pelaksana penempatan TKI, dan peningkatan kesejahteraan TKI dan keluarganya. Pasal ini jelas memberikan rumusan tugas kepada BNP2TKI untuk memberikan pelayanan, mengkoordinasikan, dan melakukan pengawasan secara umum baik penempatan TKI yang dilakukan oleh BNP2TKI sendiri maupun yang dilakukan oleh PPTKIS, karena itu pengalihan tugas ini kepada institusi lain (Direktorat Jenderal Penempatan Tenaga Kerja Depnakertrans) seperti yang diatur dalam Permenakertrans Nomor 22 Tahun 2008 tentang Pelaksanaan Penempatan dan Perlindungan TKI tidak dapat dibenarkan secara hukum karena substansinya bertentangan dengan Undang-undang Nomor 39 Tahun 2004 jo. Peraturan Pemerintah Nomor 81 Tahun 2006.

Penarikan kewenangan BNP2TKI sebagai pelaksana kebijakan penempatan dan perlindungan TKI oleh Menakertans sebagai pembuat regulasi menunjukkan adanya tarik ulur kewenangan antara dua institusi pemerintah tersebut. Padahal dalam Pasal 48 Peraturan Presiden Nomor 81 Tahun 2006 menetapkan bahwa dengan terbentuknya BNP2TKI, maka Direktorat Jenderal Pembinaan Penempatan Tenaga Kerja Luar Negeri Depnakertrans dihapus. Demikian halnya dengan seluruh dokumen yang berkaitan dengan penempatan dan perlindungan TKI serta pegawainya dalam jangka waktu paling lama enam bulan harus dialihkan pada BNP2TKI (Pasal 49 huruf $b, c)$. Namun ternyata Direktorat tersebut masih tetap ada dan melaksanakan tugas dan fungsi Direktorat Jenderal Pembinaan Penempatan TKI Luar Negeri dengan perubahan nomenklatur menjadi Direktorat Jenderal Pembinaan Penempatan Tenaga Kerja yang betugas merumuskan kebijakan serta melaksanakan kebijakan dan standarisasi teknis di bidang 
Pembinaan Penempatan Tenaga Kerja (Pasal 5 Keputusan Presiden Nomor 7 Tahun 2007).

Sesuai dengan teori hukum, maka penyelesaian terhadap inkonsistensi secara vertikal atau konflik norma hukum (antinomi) antara peraturan yang lebih rendah dengan peraturan yang lebih tinggi tingkatannya, maka mekanisme penyelesaian (legal remedies) dilakukan dengan menggunakan asas hukum umum yakni "Lex superior derogat legi inferiori" (peraturan yang lebih tinggi tingkatannya mengesampingkan peraturan yang lebih rendah).

\section{Sinkronisasi Horizontal/Harmonisasi}

Istilah harmonisasi secara etimologis berasal dari kata dasar harmoni, menunjuk pada suatu proses yang bermula dari suatu upaya untuk menuju atau merealisasi sistem harmoni. Istilah harmoni juga diartikan sebagai keselarasan, kecocokan, keserasian, keseimbangan. ${ }^{15}$ Dalam bahasa Inggris dikenal dengan istilah harmonization yang berasal dari kata kerja harmonize yang berarti "to be or make something harmonious" (menjadikan atau membuat sesuatu sesuai atau selaras). ${ }^{16}$ Istilah harmoni berasal dari bahasa Yunani yaitu "harmonia" yang artinya terikat secara serasi dan sesuai. Dalam makna filsafat diartikan sebagai "kerjasama antar berbagai faktor yang sedemikian rupa, hingga faktor-faktor tersebut menghasilkan kesatuan yang luhur". ${ }^{17}$ Jadi ketidaksinkronan atau ketidak harmonisan yang dimaksudkan adalah ketidakselarasan atau ketidakcocokan antara peraturan perundangundangan yang satu dengan lainnya.

Dari pengertian di atas jelaslah bahwa harmonisasi memiliki kedekatan makna dengan sinkronisasi yakni sebagai kesesuaian, keselarasan, kecocokan. Atas dasar itu dalam kajian ilmu hukum, dikenal adanya sinkronisasi vertikal dan sinkronisasi horizontal atau harmonisasi. Dalam sinkronisasi horizontal yang dikaji adalah peraturan perundang-undangan yang sederajat yang mengatur mengenai bidang yang sama. ${ }^{18}$ Bidang yang sama yang dimaksudkan adalah peraturan perundangan yang memiliki kesamaan pengaturan substansi atau memiliki relevansi dengan bidang yang

\footnotetext{
${ }^{15}$ Kusnu Goesniadhie, Op. Cit., hal. 59.

${ }^{16}$ A.S. Hornby, Op. Cit., hal. 554.

${ }^{17} \mathrm{Ibid}$.

${ }^{18}$ Soerjono Soekanto dan Sri Mamudji, Loc. Cit.
} 
dikaji. Inkosistensi peraturan perundang-undangan secara horizontal terjadi dari substansi peraturan, yakni beberapa peraturan yang secara hierarkhis sejajar, misalnya sesama undang-undang tetapi substansi yang satu lebih umum dari yang lain. ${ }^{19}$ Peraturan perundang-undangan dimaksud dalam kaitannya dengan penempatan dan perlindungan TKI yang bekerja di luar negeri adalah:

\section{Undang-undang No. 39 Tahun 1999 tentang HAM}

Manusia dianugerahi oleh Tuhan yang Maha Esa akal budi dan nurani yang memberikan kepadanya kemampuan untuk membedakan yang baik dan yang buruk yang akan membimbing dan mengarahkan sikap dan perilaku dalam menjalani kehidupannya. Dengan akal budi dan nuraninya itu, maka manusia memiliiki kebebasan untuk memutuskan sendiri perilaku atau perbuatannya. Di samping itu, untuk mengimbangi kebebasan tersebut manusia memiliki kemampuan untuk bertanggung jawab atas semua tindakan yang dilakukannya. Kebebasan dasar dan hak-hak dasar itulah yang disebut hak asasi manusia yang melekat pada manusia secara kodrati sebagai anugrah Tuhan Yang Maha Esa. Hak-hak ini tidak dapat diingkari. Pengingkaran terhadap hak tersebut berarti mengingkari martabat kemanusiaan. Untuk melindungi, mempertahankan, dan meningkatkan martabat manusia, diperlukan pengakuan dan perlindungan HAM, karena tanpa hal tersebut manusia akan kehilangan sifat dan martabatnya, sehingga dapat mendorong manusia menjadi serigala bagi manusia lainnya (homo homini lupus). Oleh karena itu, negara, pemerintah, atau organisasi apapun mengemban kewajiban untuk mengakui dan melindungi hak asasi manusia pada setiap manusia tanpa kecuali. Ini berarti bahwa hak asasi manusia harus selalu menjadi titik tolak dan tujuan dalam penyelenggaraan kehidupan bermasyarakat, berbangsa, dan bernegara. Untuk menjamin terlaksana hak tersebut, maka dibentuklah Undang-undang Nomor 39 Tahun 1999 tentang HAM.

Dasar pemikiran pembentukan Undang-undang Nomor 39 Tahun 1999 tentang HAM tersebut Pemikiran di atas, sejalan dengan pandangan Bangsa Indonesia sebagai negara anggota PBB yang memandang "Universal Declaration of Human Rights" bukan hanya sebagai "Statement of objective" semata-mata, akan tetapi

${ }^{19}$ Gatot Dwi Hendro, Loc. Cit. 
menyakininya sebagai "constitutes an obligation for the members of the international community" yang harus dijamin dan ditegakkan.

Undang-undang Nomor Nomor 39 Tahun 2004 tentang Penempatan dan Perlindungan Tenaga Kerja Indonesia di Luar Negeri pada bagian konsideran menimbang menyebutkan bahwa (1) bekerja merupakan HAM yang wajib dijunjung tinggi, dihormati, dan dijamin penegakannya, (2) tenaga kerja Indonesia di luar negeri sering dijadikan obyek perdagangan manusia, termasuk perbudakan dan kerja paksa, korban kekerasan, kesewenang-wenangan, kejahatan atas harkat dan mertabat manusia, serta perlakuan lain yang melanggar HAM.

Dari landasan filsafati dibentuknya Undang-undang ini jelaslah bahwa pokok pangkalnya berpijak dari konsep bekerja sebagai HAM yang wajib dihormati dan dijamin penegakannya, sementara kondisi empiris menunjukkan keprihatinan bahwa tenaga kerja Indonesia yang bekerja di luar negeri sering dijadikan obyek perdagangan manusia, termasuk perbudakan dan kerja paksa, korban kekerasan, kesewenangwenangan, kejahatan atas harkat dan mertabat manusia, serta perlakuan lain yang melanggar HAM. Namun kondisi kontradiktif tampak pada konsideran bagian mengingat hanya merujuk Pasal dalam UUD Negara Republik Indonesia Tahun 1945 dan Undang-undang Nomor 13 Tahun 2003 tentang Ketenagakerjaan, sedangkan yang lainnya seperti Undang-undang Nomor 39 Tahun 1999 tentang HAM tidak dicantumkan.

Sejalan dengan Undang-undang HAM, pemerintah juga telah meratifikasi Kovenan Internasional Tentang Hak-hak Ekonomi, Sosial dan Budaya (International Covenant on Economic, Social and Cultural Rights) melalui Undang-undang RI Nomor 11 Tahun 2005. Kovenan ini mengukuhkan dan menjabarkan pokok-pokok HAM di bidang ekonomi, sosial dan budaya dari UDHR atau DUHAM yang merupakan HAM generasi kedua ke dalam ketentuan-ketentuan yang mengikat secara hukum. Intinya kovenan ini mengakui hak asasi setiap orang di bidang ekonomi, sosial, dan budaya, yang meliputi :1) hak atas pekerjaan, 2) hak untuk menikmati kondisi kerja yang adil dan menyenangkan, 3) hak untuk membentuk dan ikut serikat buruh, 4) hak atas jaminan sosial, termasuk asuransi sosial , 5) hak atas perlindungan dan bantuan yang seluas mungkin bagi keluarga, ibu, anak, dan orang muda, 6) hak atas standar kehidupan yang memadai, 7) hak untuk menikmati standar kesehatan fisik dan mental yang tertinggi yang dapat dicapai, 8) hak atas pendidikan, dan 9) hak untuk ikut serta dalam kehidupan budaya. 
Berdasarkan kedua undang-undang tersebut jelaslah bahwa secara normatif tenaga kerja yang bekerja baik di dalam negeri maupun luar negeri sudah dilindungi hak-haknya baik atas upah, jaminan sosial, kondisi kerja yang kondisif, mendirikan dan menjadi anggota serikat buruh/pekerja, pendidikan dan pelatihan kerja dan lainnya. Namun karena undang-undang ini tidak dijadikan landasan dalam pembentukan Undang-undang Nomor 39 Tahun 2004 tentang Penempatan dan Perlindungan TKI di luar negeri, maka norma-norma yang terkandung di dalamnya tidak mencerminkan prinsip perlindungan HAM tersebut.

Prinsip dimaksud adalah bekerja merupakan bagian dari HAM dan tanggung jawab negara untuk perlindungan, pemenuhan dan penegakannya. Wujud perlindungan, pemenuhan, dan penegakannya adalah melalui pengaturan dan penjabaran HAM ekonomi tersebut dalam peraturan peraturan perundangan-undangan penempatan dan perlindungan TKI, dan menjamin pemenuhan dan penegakannya. HAM ekonomi ini pada dasarnya adalah tuntutan persamaan sosial, sehingga sering disebut hak-hak positif yang pemenuhannya membutuhkan peran aktif negara. Keterlibatan negara harus menunjukkan tanda positif, tidak boleh menunjukkan tanda negatif. Jadi untuk memenuhi hak-hak yang dikelompokkan dalam ke dalam geneasi kedua ini, negara diwajibkan untuk menyusun dan menjalankan program-program bagi pemenuhan hak-hak tersebut. ${ }^{20}$

HAM ekonomi yang merupakan HAM generasi kedua muncul pada awal abad ke 19 di Perancis melalui perjuangan revulusioner memperjuangkan kesejahteraan akibat pelanggaran atau penyelewenangan kaum kapitalis yang melegitimasi eksploitasi kaum pekerja akibat sistem ekonomi kapitalis yang memberikan kebebasan berkompetisi (free competition) secara individual di bidang ekonomi.

Sampai dengan saat inipun terdapat perbedaan pandangan mengenai HAM, khususnya menyangkut HAM sipil dan politik dan HAM ekonomi. Negara-negara barat yang dipengaruhi filsafat individualisme liberal lebih mengutamakan hak-hak sipil dan politik. Bahkan mereka menganggap hak ekonomi, sosial dan budaya bukan HAM. Sebaliknya negara-negara sosialis yang dipengaruhi oleh ajaran Marxisme/Sosialisme dan negara-negara dunia ketiga memandang bahwa tugas utama negara adalah mensejahterakan masyarakat dengan

${ }^{20}$ Rhona K.M. Smith, Op. Cit., hal. 16. 
aktif mengatur ekonomi, sosial dan budaya. Karena itu, hak ekonomi, sosial dan budaya merupakan hak asasi yang lebih utama. ${ }^{21}$

\section{Undang-undang Nomor 32 Tahun 2004 tentang Pemerintahan Daerah}

Kekurangan pengaturan otonomi daerah dalam Undang-undang Nomor 22 Tahun 1999 telah disempurnakan melalui Undang-undang Nomor 32 Tahun 2004 tentang Pemerintahan Daerah. Sama halnya dengan undang-undang sebelumnya yakni menganut prinsip otonomi seluas-luasnya dalam arti daerah diberikan kewenangan untuk mengatur dan mengurus semua urusan pemerintahan di luar urusan yang merupakan kewenangan pemerintah yakni politik luar negeri, pertahanan, keamanan, moneter, yustisi, dan agama. Kewenangankewenangan ini menjadi kewenangan pemerintah karena menyangkut terjaminnya kelangsungan hidup bangsa dan negara secara keseluruhan.

Selain urusan pemerintahan yang merupakan wewenang penuh dari pemerintah, terdapat urusan pemerintahan yang bersifat concurrent artinya artinya urusan pemerintahan yang penanganannya dalam bagian atau bidang tertentu dapat dilaksanakan bersama antara pemerintah dan pemerintah daerah. Dengan demikian terdapat pembagian kewenangan antara pemerintah, ada kewenangan provinsi, dan ada bagian kewenangan urusan yang diserahkan kepada kabupaten/kota. Pembagain urusan kewenangan ditetapkan secara proporsional berdasarkan kriteria eksternalitas, akuntabilitas, dan efisiensi dengan memperhatikan keserasian hubungan antar susunan pemerintahan. Penyelenggaraan urusan pemerintahan merupakan pelaksanaan hubungan kewenangan antara pemerintah dan pemerintahan daerah provinsi, kabupaten dan kota atau antar pemerintahan daerah yang saling terkait, tergantung, dan sinergis sebagai satu sistem pemerintahan. Urusan pemerintahan yang menjadi kewenangan pemerintahan daerah, terdiri atas urusan wajib dan urusan pilihan. Urusan pemerintahan wajib adalah urusan pemerintahan yang wajib diselenggarakan oleh pemerintahan daerah yang terkait dengan pelayanan dasar (basic services) bagi masyarakat. Urusan pemerintahan yang bersifat pilihan adalah urusan pemerintahan yang

${ }^{21}$ Antonio Cassese dalam A.Latief Fariqun, Pengakuan Hak Masyarakat Hukum Adat Atas Sumber Daya Alam dalam Politik Hukum Nasional, Disertasi, Program Doktor Ilmu Hukum Fakultas Hukum, Universitas Brawujaya Malang, 2007, hal. 23. 
diperioritaskan oleh pemerintahan daerah untuk diselenggarakan yang terkait dengan upaya mengembangkan potensi unggulan (core competence) yang menjadi kekhasan daerah.

Khusus dalam bidang ketenagakerjaan yang merupakan fokus kajian ini, urusan wajib yang menjadi kewenangan pemerintahan daerah propinsi merupakan urusan dalam skala propinsi yang meliputi pelayanan bidang ketenagakerjaan lintas kabupaten/kota (Pasal 13 huruf $h$ ). Urusan wajib yang menjadi kewenangan pemerintahan daerah untuk kabupaten/kota merupakan urusan yang berskala kabupaten/kota yang meliputi pelayanan bidang ketenagakerjaan (Pasal 14 huruf h).

Penjabaran lebih lanjut mengenai pembagian urusan ini diatur dalam Peraturan Pemerintah Nomor 38 Tahun 2007 tentang Pembagian Urusan Pemerintahan antara Pemerintah, Pemerintahan Daerah Provinsi, dan Pemerintahan Daerah Kabupaten/Kota.

Dalam Peraturan Pemerintah tersebut wujud kewenangan yang diberikan kepada daerah adalah dalam bentuk pembinaan, pengawasan penempatan dan perlindungan TKI di wilayah propinsi dan kabupaten/kota. Kewenangan dalam bidang pengawasan yang dilakukan oleh instansi yang bertanggungjawab di bidang ketenagakerjaan pada pemerintah provinsi, pemerintah kabupaten/kota sesuai dengan ketentuan Pasal 92 Undang-undang Nomor 39 Tahun 2004. Selain pengawasan, pemerintah kabupaten/kota juga memiliki kewenangan dalam bidang penempatan TKI dalam bentuk pendaftaran dan seleksi calon TKI, pelayanan dan perlakuan yang sama dalam penempatan TKI di luar negeri dan pada tahap purna penempatan dalam bentuk pelayanan kepulangan TKI sesuai dengan ketentuan Pasal 8 huruf b, c Undang-undang Nomor 39 Tahun 2004 tentang Penempatan dan Perlindungan TKI di Luar Negeri.

Berdasarkan kewenangan yang diberikan kepada pemerintah provinsi dan kabupaten/kota dalam bidang penempatan dan perlindungan TKI, tampak bahwa baik Undang-undang Nomor 39 Tahun 2004 maupun Peraturan Pemerintah Nomor 38 Tahun 2007 tentang Pembagian Urusan Pemerintahan antara Pemerintah, Pemerintahan Daerah Provinsi, dan Pemerintahan Daerah Kabupaten/Kota keduanya bercorak sentralistik dalam hal perlindungan TKI. Semua perlindungan menjadi kewenangan Pemerinah Pusat dengan alasan karena perlindungan TKI berkenaan dengan hubungan dengan negara lain. Padahal perlindungan TKI tidak hanya pada saat penempatan, tapi juga pra penempatan, dan sesudah 
penempatan. Akibatnya TKI belum dapat terlindungi secara layak khususnya pada tahap pra penempatan.

Menurut penulis seiring dengan pelaksanaan otonomi daerah, maka seyogyanya untuk perlindungan pra penempatan diserahkan kepada daerah sepenuhnya karena daerah yang paling mengetahui karakteristik masyarakat dan kebutuhan daerahnya. Misalnya masalah pusat informasi dan pendaftaran calon TKI yang harus dilakukan di instansi yang bertangungjawab dalam bidang ketenagakerjaan kabupaten/kota. Aturan seperti ini kurang fungsional karena calon TKI yang kebanyakan dari pedesaan dan berpendidikan rendah itu akan mengalami kesulitan dalam mengakases informasi maupun mendaftarkan diri menjadi TKI pada Disnaker Kabupatan/Kota yang jaraknya cukup jauh dari kampung halaman TKI. Karena itu akan lebih tepat jika pusat informasi dan tempat pendaftaran itu kewenangannya diserahkan kepada pemerintah daerah kabupaten/kota, sehingga daerah memiliki keleluasaan dalam mengaturnya, misalnya melalui Peraturan Daerah (Perda). Dalam Perda yang dibuat daerah dapat menjadikan desa sebagai pusat informasi (information center) dan tempat pendaftaran calon TKI karena institusi ini paling dekat dengan masyarakat, sehingga memudahkan calon TKI untuk mengakses informasi termasuk seluruh dokumen yang diperlukan. Sistem ini sekaligus akan dapat memangkas peran calo yang selama ini banyak terlibat dalam rekrutmen dan pengurusan dokumen calon TKI.

\section{Penutup}

\section{Kesimpulan}

Dari uraian di atas dapat disimpulkan bahwa belum terlindungi TKI yang bekerja di luar negeri berdasarkan Undang-undang Nomor 39 Tahun 2004 karena norma yang diatur di dalamnya tidak sinkron secara vertikal dan horizontal.

a. Secara vertikal belum mencerminkan ketentuan Pasal 28D ayat (2) UUD Negara RI Tahun 1945 jo. Pasal $28 \mathrm{I}$ ayat (4). Selain itu Peraturan Presiden No. 81 Tahun 2006 tentang BNP2TKI tidak sinkron dengan ketentuan dalam Undangundang Nomor 39 Tahun 2004 khususnya dalam hal pengawasan perlindungan TKI. Akibatnya terjadi tumpang dindih dalam pengawasan perlindungan TKI. Demikian juga antara Kepmenakertrans Nomor 18/MEN/IX/2007 tentang 
Pelaksanaan Penempatan dan Perlindungan TKI di Luar Negeri dengan Peraturan Presiden No. 81 Tahun 2006. Kewenangan BNP2TKI di bidang penempatan dan perlindungan TKI yang diatur dalam peraturan tersebut sebagian ditarik kembali ke Depnakertrans melalui Kepmenakertrans No. 22/MEN/XXI/2008, akibatnya terjadi konflik kewenangan (conflict of authority) antara Menakertrans sebagai regulator dan BNP2TKI sebagai pelaksana kebijakan di bidang penempatan dan perlindungan TK.

b. Secara horizontal belum sinkron antara Undang-undang Nomor 39 Tahun 2004 dengan Undang-undang Nomor 39 Tahun 1999 tentang HAM khususnya menyangkut penjabaran konsep bekerja sebagai bagian dari HAM dan tanggung jawab negara dalam perlindungan, pemenuhan dan penegakannya. Hal yang sama juga terjadi dengan Undang-undang Nomor 32 Tahun 2004 tentang Pemerintahan Daerah berkaitan dengan kewenangan perlindungan TKI antara pemerintah pusat dan pemerintah daerah.

\section{Saran}

Perlu dilakukan pembaharuan hukum (legal reform) terhadap substansi Undang-undang Nomor 39 Tahun 2004 tentang Penempatan dan Perlindungan Terhadap TKI di Luar Negeri khususnya dalam menyelaraskan norma yang bertentangan satu sama lain baik secara vertikal maupun horizontal. 


\section{Daftar Pustaka}

Anonim, Kamus Besar Bahasa Indonesia, Departeman Pendidikan dan Kebudayaan, Balai Pustaka, Jakarta, 1997.

"Devisa TKI Tembus Rp. 130 Triliun". Jawa Pos, 16 Desember 2008, Allot, Antony, The Limits of Law, Butterworths, London, 1980.

Fariqun, A.Latief, "Pengakuan Hak Masyarakat Hukum Adat Atas Sumber Daya Alam dalam Politik Hukum Nasional", Disertasi, Program Doktor Ilmu Hukum Fakultas Hukum, Universitas Brawujaya Malang, 2007.

Goesniadhie, Kusnu S, Harmonisasi Hukum dalam Perspektif Perundang-undangan, JP Books, Surabaya, 2006.

Hidayati, "Menghitung Angka Pengangguran dan Harapan yang Raib", Kompas, Tanggal, 12 Pebruari, 2005, Jakarta.

Homby, AS, Oxford Advanced Leaner's Dictionary. Oxford University, 1995.

Hendro, Gatot Dwi, "Kerangka Hukum Pengelolaan Ekosistem Terumbu Karang untuk Mendukung Pemanfaatan Berkelanjutan Keanekaragaman Hayati Lautan", Disertasi, Program Pascasarjana Universitas Airlangga, Surabaya, 2007.

HR, Ridwan, Hukum Administrasi Negara, RajaGrafindo Persada, Jakarta, 2007.

Hadjon, Philipus M, "Penegakan Hukum Administrasi dalam Pengelolaan Lingkungan Hidup", Makalah Lokakarya Penegakan Hukum Lingkungan, Unair, Surabaya, 1996.

Naovalita, Tita, dkk, Perlindungan Sosial Buruh Migran Perempuan, Proseding Seminar, The world Bank bekerjasama dengan Kementerian Kesejahteraan Rakyat RI, Jakarta, 2-3 Mei 2006.

Soekanto, Soerjono, dan Sri Mamudji, Penelitian Hukum Normatif Suatu Tinjauan Ringkas, Rajawali Pers, Jakarta, 1985. 